\title{
RESPON PERKECAMBAHAN BENIH ASAM JAWA (Tamarindus indica) TERHADAP BERBAGAI KONSENTRASI LARUTAN KALIUM NITRAT $\left(\mathrm{KNO}_{3}\right)$
}

\section{(TAMARIND (Tamarindus indica) SEED GERMINATION RESPONSE TO

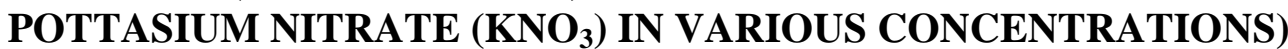

\author{
Elfri Mentari Situmorang, Melya Riniarti, dan Duryat \\ Jurusan Kehutanan Fakultas Pertanian Universitas Lampung \\ J1. Soemantri Brojonegoro No. 1 Bandar Lampung \\ Email : sunriseepi@yahoo.com, Phone : 085769957649
}

\begin{abstract}
ABSTRAK
Asam jawa (Tamarindus indica) termasuk pohon multiguna yang dapat dikembangkan dengan suatu perbanyakan, baik secara vegetatif maupun generatif. Perbanyakan asam jawa secara vegetatif dapat menghasilkan buah berlimpah apabila organ tanamannya berasal dari pohon induk yang bergenetik unggul. Namun karena jarangnya ketersediaan tegakan asam jawa di alam saat ini, maka perbanyakan secara generatif dengan biji, dapat menjadi pilihan yang tepat dalam membudidayakannya. Umumnya benih asam jawa bersifat dorman, sehingga membutuhkan suatu perlakuan pendahuluan untuk mematahkan dormansinya. Salah satu cara pematahan dormansi benih adalah dengan menggunakan larutan $\mathrm{KNO}_{3}$. Penelitian ini bertujuan untuk mengetahui respon perkecambahan benih asam jawa terhadap perendaman dengan larutan $\mathrm{KNO}_{3}$ pada berbagai konsentrasi dan konsentrasi larutan $\mathrm{KNO}_{3}$ yang paling efektif untuk mempercepat perkecambahan benih asam jawa. Penelitian dilaksanakan di rumah kaca Balai Pengawasan dan Sertifikasi Benih Tanaman Pangan dan Hortikultura (BPSBTPH) Provinsi Lampung, dari bulan Juli sampai Agustus 2013. Penelitian disusun dalam Rancangan Acak Lengkap (RAL), dengan 5 perlakuan perendaman larutan $\mathrm{KNO}_{3}$ (konsentrasi 0,1\%, 0,2\%, 0,3\%, 0,4\% dan tanpa $\mathrm{KNO}_{3}$ ) dan 3 ulangan. Setiap unit percobaan terdiri dari 100 benih. Parameter yang diamati meliputi persentase berkecambah, rata-rata hari berkecambah, dan persentase benih berkecambah per hari. Homogenitas data diuji dengan uji Bartlett. Setelah data homogen, dilakukan analisis sidik ragam. Analisis lanjutan dilakukan dengan uji Beda Nyata Jujur (BNJ). Seluruh perhitungan data dilakukan pada taraf nyata $5 \%$. Hasil penelitian menunjukkan bahwa perendaman benih asam jawa dengan air ta-war selama 24 jam memberikan pengaruh terbaik dalam mematahkan dormansi benih asam jawa, dan konsentrasi larutan $\mathrm{KNO}_{3}$ yang paling efektif dalam mematahkan dormansi benih asam jawa adalah $0,4 \%$.
\end{abstract}

Kata kunci : asam jawa, dormansi, kalium nitrat, perkecambahan

\section{ABSTRACT}

Tamarind (Tamarindus indica) is a multipurpose tree that can be developed either vegetative or generative propagation. Vegetative propagation of tamarind can produce abundant fruit if the plant organs derived from superior parent trees. However, due to the rare availability of natural tamarind stands now days, then the generative propagation by seed, can be the right choice for its cultivation. Generally, tamarind seeds are dormant, so it requires a pretreatment to break its dormancy. One way to break it was using potassium nitrate $\left(\mathrm{KNO}_{3}\right)$. This study aimed to determined the response of soaking treatment to the germination of tamarinds seeds with $\mathrm{KNO}_{3}$ solution at various concentrations and the most effective concentration of $\mathrm{KNO}_{3}$ solution to stimulate tamarind seeds germination. The experiment was con- 
ducted at the Greenhouse Seed Control and Certification Institute of Food Crops and Horticulture (BPSBTPH) Lampung Province, from July to August 2013. This research used Completely Randomized Design (CRD), with 5 treatment of $\mathrm{KNO}_{3}$ solution soaking $(0,1 \%$, 0,2\%, 0,3\%, 0,4\% and without $\mathrm{KNO}_{3}$ ) and 3 replications. Every unit of experiments consisted of 100 seeds. Observed parameters included percentage of germination, mean of day germination and percentage of germination seeds per day. Bartlett test was employed to figure out the homogenity of datas. Then, analysis of variance was used to analyse datas. Honestly Significant Difference (HSD) was used to the advanced analysis. The entire data tested on 5\% significant level. The result showed that soaking of tamarind seeds in water (without $\mathrm{KNO}_{3}$ ) during 24 hours gave the best response to break its dormancy, and the most effective concentration to break dormancy of tamarind seeds was $0,4 \%$.

Keywords: dormancy, germination, pottasium nitrate, tamarind

\section{PENDAHULUAN}

Asam jawa (Tamarindus indica) merupakan tanaman tropis penghasil buah yang termasuk da-lam famili Caesalpiniaceae. Asam jawa juga dikategorikan pohon multiguna karena hampir seluruh bagian pohonnya dapat dimanfaatkan. Kayu asam jawa dapat digunakan sebagai ba-han mebel, kayu bakar dan arang. Buah asam jawa dapat dikonsumsi dan digunakan sebagai bumbu masak. Kandungan vitamin B yang terdapat dalam daging buah, sangat baik untuk ke-sehatan (Departemen Kehutanan, 2002). Biji asam jawa juga dapat digunakan sebagai koa-gulan alami dalam perbaikan kualitas air tanah, khususnya untuk menurunkan angka total koliform pada air tanah (Hendrawati dkk., 2013). Selain itu, akar pohon asam jawa yang da-lam, membuat jenis ini sangat tahan terhadap badai dan cocok sebagai pemecah angin (wind breaker) (Departemen Kehutanan, 2002). Asam jawa juga dikenal masyarakat sebagai pohon rindang dan ditemukan hampir di seluruh wilayah Indonesia, sehingga di berbagai daerah sa-ngat cocok digunakan sebagai pohon pelindung (Sundari dan Winarno, 2010).

Asam jawa dapat dibudidayakan secara vegetatif dan generatif. Perbanyakan vegetatif dapat dilakukan dengan setek, cangkok, okulasi dan sambung dari bahan tanaman. Perbanyakan asam jawa secara vegetatif dapat menghasilkan buah berlimpah apabila organ tanamannya berasal dari pohon induk yang bergenetik unggul. Namun, karena saat ini jarang ditemukan tegakan asam jawa, maka perbanyakan secara generatif dapat menjadi pilihan yang tepat da-lam membudidayakannya.

Benih asam jawa termasuk benih ortodok, sehingga dapat disimpan dalam jangka waktu yang cukup lama. Benih ortodok dapat dikeringkan sampai kadar air rendah 5--10\% dan dapat di-simpan pada suhu serta kelembaban penyimpanan yang rendah tanpa menyebabkan penu-runan viabilitas (Mudiana, 2007). Umumnya benih ortodok mengalami masa dormansi, yaitu masa dimana benih tidak dapat berkecambah dengan segera meskipun berada pada ling-kungan yang sesuai bagi perkecambahannya. Dorman pada benih asam jawa merupakan dor-mansi fisik. Kulit benih yang impermeabel menjadikan benih sulit untuk dimasuki oleh air saat proses imbibisi. Oleh karena itu, benih asam jawa membutuhkan suatu perlakuan penda-huluan untuk mematahkan dormansinya.

Ada beberapa teknik untuk mematahkan dormansi yaitu dengan skarifikasi secara mekanis, fisik maupun kimia. Salah satu cara efektif pematahan dormansi adalah dengan mengguna-kan larutan kimia. Tujuan utama yang diharapkan adalah memudahkan proses imbibisi, de-ngan menjadikan kulit biji menjadi permeabel sehingga mudah dimasuki oleh air saat proses imbibisi. Berbagai larutan yang biasa dipakai untuk pemecahan dormansi 
diantaranya adalah larutan $\mathrm{KNO}_{3}, \mathrm{H}_{2} \mathrm{SO}_{4}, \mathrm{HCl}$, dan larutan lainnya (Sutopo, 2002). Larutan kalium nitrat $\left(\mathrm{KNO}_{3}\right)$ merupakan salah satu senyawa kimia yang berpotensi untuk mematahkan dormansi suatu benih (Kartasapoetra, 2003). Karakteristik larutan $\mathrm{KNO}_{3}$ yang relatif ekonomis, aman dan mudah digunakan, menjadi alasan banyak penelitian ilmiah mengenai pematahan dor-mansi menggunakan larutan tersebut.

Penelitian Anwar dkk. (2008) menyatakan bahwa perlakuan yang diberikan pada benih Andalas (Morus macroura) berumur 24 hari, dengan perendaman dalam larutan $\mathrm{KNO}_{3}$ konsentrasi $0,2 \%$ selama 60 menit menghasilkan persentase perkecambahan yang cukup tinggi yaitu sebesar $91 \%$ dibandingkan dengan perendaman aquades dan perendaman air kelapa muda 25\% selama 60 menit yaitu sebesar 85,5\%, dan 90,5\% secara berturut-turut. Penelitian lainnya yang dilakukan oleh Winarni (2009) menyebutkan bahwa perlakuan pendahuluan yang diaplikasikan pada kayu afrika (Maesopsis eminii) dengan perendaman larutan $\mathrm{KNO}_{3}$ 0,2\% selama 45 menit dapat meningkatkan rata-rata perkecambahan sebesar $94 \%$ dan memberikan hasil yang paling baik dibandingkan dengan perendaman larutan $\mathrm{KNO}_{3} \quad 0,2 \%$ selama 15 menit dan perendaman larutan $\mathrm{KNO}_{3}$ 0,2\% selama 30 menit.

Tujuan penelitian ini adalah untuk mengetahui respon perkecambahan benih asam jawa terha-dap perendaman dengan larutan $\mathrm{KNO}_{3}$ berbagai konsentrasi, dan mengetahui konsentrasi la-rutan $\mathrm{KNO}_{3}$ yang paling efektif untuk mempercepat perkecambahan benih asam jawa. Hipo-tesis yang diajukan adalah perendaman pada berbagai konsentrasi larutan $\mathrm{KNO}_{3}$, berpengaruh terhadap perkecambahan benih asam jawa, dan konsentrasi larutan $\mathrm{KNO}_{3}$ sebesar $0,2 \%$, berpengaruh lebih efektif dibandingkan kontrol, konsentrasi $0,1 \%$, $0,3 \%$ dan $0,4 \%$ dalam mem-percepat perkecambahan benih asam jawa.

\section{METODE PENELITIAN}

\section{Lokasi dan Waktu Penelitian}

Penelitian dilaksanakan di rumah kaca (greenhouse) Unit Pelaksana Teknis Dinas (UPTD) Pertanian Balai Pengawasan dan Sertifikasi Benih Tanaman Pangan dan Hortikultura (BPSBTPH) Provinsi Lampung. Penelitian berlangsung selama (lebih kurang) 2 bulan, yaitu pada Juli-Agustus 2013.

\section{Bahan dan Alat}

Bahan-bahan yang digunakan dalam penelitian adalah benih asam jawa, larutan $\mathrm{KNO}_{3}$, air tawar, pasir dan kertas substrat. Alat-alat yang digunakan adalah bak kecambah, gelas ukur, timbangan analitik, gembor, ayakan, kompor, dan wajan.

\section{Metode Penelitian}

\section{Rancangan Percobaan}

Rancangan yang digunakan dalam penelitian adalah Rancangan Acak Lengkap (RAL) dengan 5 perlakuan. Perlakuan berupa perendaman selama 24 jam yang terdiri dari : $\mathrm{P}_{0}$ (perendaman dengan air tawar), $\mathrm{P}_{1}$ (perendaman dengan larutan $\mathrm{KNO}_{3} 0,1 \%$ ), $\mathrm{P}_{2}$ (perendaman dengan larutan $\mathrm{KNO}_{3} 0,2 \%$ ), $\mathrm{P}_{3}$ (perendaman dengan larutan $\mathrm{KNO}_{3} 0,3 \%$ ), dan $\mathrm{P}_{4}$ (perendaman dengan larutan $\mathrm{KNO}_{3} 0,4 \%$ ). Setiap perlakuan terdiri atas 3 ulangan dan setiap unit percobaan terdiri dari 100 sampel benih asam jawa.

\section{Kegiatan Penelitian}

a. Pemrosesan awal benih

Benih asam jawa dikumpulkan dengan cara memungut buah dari pohon jatuhan yang terletak di sekitar BPSBTPH Bandar Lampung. Buah-buah tersebut diekstraksi, kemudian dijemur selama 3--5 hari sebelum dikecambahkan. Benih yang telah diekstraksi, selanjut- 
nya diseleksi dengan merendamnya dalam air, dan benih yang digunakan adalah benih yang tenggelam. Setelah itu, benih ditimbang per 100 butir benih dengan timbangan analitik. Penyeleksian benih dilakukan dengan tujuan untuk mendapatkan bobot benih yang relatif seragam dan berpotensi tumbuh dengan baik. Bobot benih asam jawa yang diperoleh yaitu rata-rata sebesar $1,05 \mathrm{~g} / \mathrm{benih}$.

\section{b. Persiapan media kecambah}

Media kecambah yang digunakan adalah pasir. Media kecambah tersebut sebelumnya diayak dengan tujuan untuk menghasilkan pasir yang lebih halus serta disterilkan dengan cara disangrai untuk menghindari cendawan yang hidup di dalam pasir.

\section{c. Perlakuan perendaman benih dengan larutan $\mathrm{KNO}_{3}$}

Benih-benih asam jawa terseleksi kemudian direndam ke dalam larutan $\mathrm{KNO}_{3}$ berkonsentrasi $0,1 \%, 0,2 \%, 0,3 \%, 0,4 \%$ dan air tawar (kontrol) selama 24 jam.

d. Pengecambahan benih

Benih-benih asam jawa yang telah diberi perlakuan perendaman, kemudian dikecambahkan dengan cara membenamkan benih pada media kecambah sedalam 1--2 cm.

e. Pemeliharaan

Kegiatan pemeliharaan pada penelitian benih asam jawa adalah terdiri dari penyiraman dan pembersihan gulma. Penyiraman dilakukan sebanyak 2 kali dalam sehari. Hal tersebut di-maksudkan untuk tetap mempertahankan kelembaban media kecambah. Pembersihan gulma dilakukan dengan cara manual, yaitu dengan mencabut tanaman pengganggu yang hidup di sekitar media kecambah. Kegiatan ini hanya dilakukan sesuai dengan kondisi (ada tidaknya gulma pada media perkecambahan).

\section{f. Pengamatan}

Parameter yang diamati dan dihitung pada penelitian yaitu (Indriyanto, 2011) :

1. Persentase Jumlah Benih Berkecambah (G)

$$
\mathrm{G}=\frac{\text { jumlah benih yang berkecambah }}{\text { jumlah benih yang dikecambahkan }} \times 100 \%
$$

2. Rata-rata Hari Berkecambah (GR)

$$
\begin{aligned}
& \mathrm{GR}=\frac{n 1 \times h 1+n 2 \times h 2+\cdots+(n k \times h k)}{n 1+n 2+\cdots+n k} \\
& \mathrm{n}=\text { jumlah benih berkecambah } \\
& \mathrm{h}=\text { hari dalam proses perkecambahan benih } \\
& \mathrm{k}=\text { jumlah hari yang diperlukan dalam pengamatan perkecambahan benih }
\end{aligned}
$$

3. Rata-rata Persentase Jumlah Benih Berkecambah per Hari (MDG)

$\mathrm{MDG}=\frac{\text { persentase jumlah benih berkecambah pada akhir pengamatan }}{\text { jumlah hari hingga akhir pengamatan }}$

\section{Analisis Data}

a. Homogenitas ragam

Untuk menguji homogenitas ragam, dilakukan Uji Bartlett dengan taraf nyata 5\% (Gaspersz, 1994).

\section{b. Sidik ragam}

Untuk menguji hipotesis ada atau tidaknya pengaruh faktor perlakuan terhadap parameter yang diamati, dilakukan analisis sidik ragam (uji F) dengan taraf nyata 5\%.

\section{c. Uji Beda Nyata Jujur (BNJ)}

Untuk menunjukkan perbedaan masing-masing perlakuan atau beda nyata antar perlakuan, dilakukan uji Beda Nyata Jujur (BNJ) dengan taraf nyata 5\% (Sastrosupadi, 2000). 


\section{HASIL DAN PEMBAHASAN}

\section{Hasil}

Rekapitulasi hasil analisis sidik ragam menunjukkan bahwa paling tidak terdapat satu per-lakuan perendaman benih asam jawa dengan larutan $\mathrm{KNO}_{3}$ yang memberi pengaruh yang ber-beda nyata terhadap persentase perkecambahan dan persentase benih berkecambah per hari pada taraf nyata 5\%. Rekapitulasi hasil analisis ragam disajikan pada Tabel 1.

Tabel 1. Rekapitulasi sidik ragam terhadap seluruh parameter penelitian pada perkecambahan benih asam jawa setelah direndam dengan larutan $\mathrm{KNO}_{3}$ berbagai konsentrasi.

\begin{tabular}{clcc}
\hline No. & $\begin{array}{l}\text { Parameter penelitian perkecambahan benih asam } \\
\text { jawa dengan berbagai konsentrasi larutan } \mathrm{KNO}_{3}\end{array}$ & $\mathrm{~F}_{\text {Hitung }}$ & $\mathrm{F}_{\text {Tabel 5\% }}$ \\
\hline 1. & Rata-rata persentase jumlah benih berkecambah & $4,47^{*}$ & 3,48 \\
2. & Rata-rata hari berkecambah & $3,37 \mathrm{tn}$ & 3,48 \\
3. & Rata-rata persentase jumlah benih berkecambah & $4,47^{*}$ & 3,48 \\
& per hari & & \\
\hline
\end{tabular}

Keterangan : $*$ berbeda nyata pada taraf nyata $5 \%$

tn $=$ tidak berbeda nyata

Untuk mengetahui perlakuan yang memberi pengaruh yang berbeda nyata terhadap persentase perkecambahan dan persentase benih berkecambah per hari, maka dilakukan uji Beda Nyata Jujur (BNJ). Rekapitulasi hasil analisis uji BNJ pada perendaman dengan larutan $\mathrm{KNO}_{3}$ ber-bagai konsentrasi terhadap perkecambahan benih asam jawa, disajikan pada Tabel 2.

Tabel 2. Rekapitulasi uji BNJ perkecambahan benih asam jawa setelah direndam dengan larutan $\mathrm{KNO}_{3}$ berbagai konsentrasi.

\begin{tabular}{ccc}
\hline \multirow{2}{*}{$\begin{array}{c}\text { Perendaman dengan berbagai } \\
\text { konsentrasi larutan } \mathrm{KNO}_{3} \\
\text { pada perkecambahan benih } \\
\text { asam jawa }\end{array}$} & \multicolumn{2}{c}{$\begin{array}{c}\text { Parameter penelitian perkecambahan } \\
\text { benih asam jawa }\end{array}$} \\
\cline { 2 - 3 } & $\begin{array}{c}\text { Rata-rata persentase jumlah benih } \\
\text { berkecambah }(\%)\end{array}$ & $\begin{array}{c}\text { Rata-rata persentase jumlah } \\
\text { benih berkecambah per hari } \\
(\% / \text { hari })\end{array}$ \\
\hline Air tawar $\left(\mathrm{kontrol}^{2}\right)$ & $96,33 \mathrm{abc}$ & $2,41 \mathrm{abc}$ \\
Larutan $\mathrm{KNO}_{3} 0,1 \%$ & $79,00 \mathrm{~d}$ & $1,97 \mathrm{~d}$ \\
Larutan $\mathrm{KNO}_{3} 0,2 \%$ & $83,33 \mathrm{~cd}$ & $2,08 \mathrm{~cd}$ \\
Larutan $\mathrm{KNO}_{3} 0,3 \%$ & $84,00 \mathrm{bcd}$ & $2,10 \mathrm{bcd}$ \\
Larutan $\mathrm{KNO}_{3} 0,4 \%$ & $93,00 \mathrm{abcd}$ & $2,32 \mathrm{abcd}$ \\
\hline $\mathrm{BNJ}_{0,05}$ & 14,95 & 0,37 \\
\hline $\mathrm{K}_{0}$ & 2,95 &
\end{tabular}

Keterangan : angka diikuti huruf yang sama tidak berbeda nyata pada taraf 5\%

\section{Pembahasan}

Pada perlakuan perendaman benih asam jawa dengan larutan $\mathrm{KNO}_{3}, 0,2 \%, 0,3 \%, 0,4 \%$ tidak berbeda nyata dengan perendaman benih asam jawa dalam air tawar (kontrol). Hal ini diduga karena perendaman benih asam jawa dengan air ternyata sudah mampu melunakkan kulit be-nihnya sehingga benih asam jawa mampu berimbibisi dan melanjutkan proses perkecam-bahannya. Payung dkk. (2012) dalam penelitiannya, dengan perendaman air dingin selama 24 jam pada benih sengon (Paraserianthes falcataria), menghasilkan persentase perkecambahan benih tertinggi yaitu sebesar 99,25\% dibandingkan dengan 
perendaman dalam air mendidih selama 1 menit, perendaman dalam air mendidih selama 5 menit, dan tanpa perlakuan (kontrol). Menurut Schmidt (2000), baik jenis benih dorman maupun benih yang tidak mengalami masa dormansi, dapat dipatahkan dengan perendaman dalam air selama $12-24$ jam sebelum penaburan.

Menurut Marthen dkk. (2013), air mutlak diperlukan untuk proses perkecambahan. Perke-cambahan tidak akan dimulai bila air belum terserap masuk ke dalam biji. Menurut Sutopo (2002), tahap pertama suatu perkecambahan benih dimulai dari penyerapan air oleh benih, di-lanjutkan dengan respirasi, perombakan cadangan makanan, diikuti dengan aktivitas enzim dan proses pengembangan dan pembesaran pada sel-sel di titik tumbuh. Sadjad dkk. (1980) menambahkan, proses air masuk ke dalam benih tergantung pada 3 hal yaitu komposisi ki-miawi benih, permeabilitas kulit benih, dan adanya air dalam bentuk cair ataupun uap di seki-tar benih. Proses air masuk ke dalam benih tidak ada kaitannya dengan hidup atau matinya benih. Namun jelas berhubungan dengan sifat-sifat kimiawi dari kulit benih dan sifat tanggap benih terhadap ketersediaan air di sekitarnya.

Perlakuan perendaman benih asam jawa dengan larutan $\mathrm{KNO}_{3} \quad 0,1 \%$ berbeda nyata dengan perendaman benih asam jawa dalam air tawar (kontrol), namun persentase perkecambahan dan persentase benih berkecambah per hari hasilnya cenderung lebih rendah. Hal ini diduga karena konsentrasi larutan $\mathrm{KNO}_{3}$ sebesar $0,1 \%$ dianggap belum cukup untuk memacu perke-cambahan benih asam jawa. Menurut Sadjad dkk. (1980), rangsangan yang diberikan $\mathrm{KNO}_{3}$ tergantung pada konsentrasinya. Besar kecilnya persentase perkecambahan suatu benih ber-gantung pada tinggi rendahnya konsentrasi $\mathrm{KNO}_{3}$ yang diberikan pada benih. Bustamam (1989) dalam Anwar dkk. (2008) menyatakan, dengan diberikannya $\mathrm{KNO}_{3}$ pada benih, terjadi perubahan konsentrasi antara zat penghambat dan zat perangsang perkecambahan di dalam benih. Dalam hal ini, jumlah zat perangsang meningkat dan jumlah zat penghambat tetap, se-hingga terjadi perkecambahan.

Wanafiah (2001), reaksi $\mathrm{KNO}_{3}$ sebagai zat perangsang dimulai dari proses terurainya $\mathrm{KNO}_{3}$ menjadi nitrat $\left(\mathrm{NO}_{3}{ }^{-}\right)$dan tereduksi menjadi nitrit $\left(\mathrm{NO}_{2}\right)$. Nitrat dalam perkecambahan benih berfungsi sebagai aseptor hidrogen yang membantu proses reaksi NADPH. Nitrat dalam per-kecambahan benih bertindak setelah tereduksi menjadi nitrit/hidroksilamin. Nitrit/hidrok-silamin tersebut merangsang perkecambahan dengan cara menghambat enzim katalase. Peng-hambatan tersebut menyebabkan oksigen tersedia dalam bentuk $\mathrm{H}_{2} \mathrm{O}_{2}$ untuk aktivitas perok-sidase yang terlibat dalam sistem enzim reaksi oksidasi NADPH. Hasil reaksi inilah yang mengaktifkan kembali lintasan pentosa fosfat, sehingga proses perkecambahan dapat terjadi dengan baik. Firmansyah dkk. (2007), kalium $\left(\mathrm{K}^{+}\right)$pada pertumbuhan berfungsi sebagai kofaktor fungsional dalam sintesis protein, osmosis, dan keseimbangan ion dalam sel. Namun tidak dijelaskan secara detail mengenai proses fisiologisnya. Oleh karena itu, penambahan konsentrasi $\mathrm{KNO}_{3}$ pada benih asam jawa dibutuhkan untuk mampu memacu perkecambahan benih asam jawa.

Sementara itu, seluruh perlakuan perendaman benih asam jawa dengan larutan $\mathrm{KNO}_{3}$ ber-bagai konsentrasi tidak berbeda nyata dengan perendaman benih asam jawa dalam air tawar (kontrol) terhadap rata-rata hari berkecambah. Hal ini diduga karena benih asam jawa yang digunakan baru diunduh dan belum mengalami proses penyimpanan, sehingga memiliki via-bilitas benih yang masih sangat baik dan memiliki kemampuan untuk menyuplai makanannya sendiri untuk proses perkecambahannya. Menurut Schmidt (2000), benih masak segar selalu mempunyai kualitas fisiologis tertinggi. Apabila benih langsung disemai setelah pemrosesan awal, tidak saja menghemat biaya penyimpanan, tetapi juga mampu menghasilkan perkecam-bahan dan kualitas semai terbaik. Sutopo (2002) menambahkan, benih yang belum masak be-nar, menghasilkan persentase perkecambahan yang lebih rendah dibandingkan benih yang masak dan memberikan perbedaan waktu yang diperlukan untuk berkecambah, meskipun ka-pasitas perkecambahannya sama. 


\section{KESIMPULAN}

Dari hasil penelitian, dapat disimpulkan sebagai berikut.

1. Perendaman benih asam jawa dengan air tawar selama 24 jam memberikan pengaruh terbaik dalam mematahkan dormansi benih asam jawa.

2. Konsentrasi larutan $\mathrm{KNO}_{3}$ yang paling efektif dalam mematahkan dormansi benih asam jawa adalah $0,4 \%$.

\section{DAFTAR PUSTAKA}

Anwar, A., Renfiyeni, dan Jamsari. 2008. Metode perkecambahan benih tanaman andalas (Morus macroura Miq.). Jurnal Jerami. 1(1):1--5.

Departemen Kehutanan. 2002. Informasi singkat benih Tamarindus indica L. Artikel. Direktorat Perbenihan Tanaman Hutan. Bandung. No.21.

Firmansyah, R., A. Mawardi H., dan M. Umar Riandi. 2007. Mudah dan Aktif Belajar Biologi. Buku. Setia Purna Inves. Bandung. 218 p.

Gaspersz, V. 1994. Metode Rancangan Percobaan. Buku. Armico. Bandung. 472 p.

Hendrawati, Syamsumarsih, dan Nurhasni. 2013. Penggunaan biji asam jawa (Tamarindus indica L.) dan biji kecipir (Psophocarpus tetragonolobus L.) sebagai koagulan alami dalam perbaikan kualitas tanah. Prosiding Semirata FMIPA. 10--12 Mei 2013. Universitas Lampung. Lampung. 179-191.

Indriyanto. 2011. Panduan Praktikum Teknik dan Manajemen Bibit/Persemaian. Modul. Fakultas Pertanian Universitas Lampung. Bandar Lampung. 70 p.

Kartasapoetra, A. G. 2003. Teknologi Benih. Buku. Rineka Cipta. Jakarta. 188 p.

Marthen, E. Kaya, dan H. Rehatta. 2013. Pengaruh perlakuan pencelupan dan perendaman terhadap perkecambahan sengon (Paraserianthes falcataria). Jurnal Agrologia. 2(1):10--16.

Mudiana, D. 2007. Perkecambahan Syzygium cumini (L.) Skeels. Jurnal Biodiversitas. 8(1):39--42.

Payung, D., E. Prihatiningtyas, dan S. H. Nisa. 2012. Uji daya kecambah benih sengon (Paraserianthes falcataria (L.) Nielsen) di greenhouse. Jurnal Hutan Tropis. 1(2):132--138.

Sadjad, S., H. Suseno, S. S. Harjadi, Sugiharso, dan Sudarsono. 1980. Dasar-Dasar Teknologi Benih Capita Selecta. Buku. Institut Pertanian Bogor. 216 p.

Sastrosupadi. 2000. Rancangan Percobaan Praktis Bidang Pertanian. Buku. Kanisius. Malang. $276 \mathrm{p}$.

Schmidt, L. 2000. Pedoman Penanganan Benih Tanaman Hutan Tropis dan Subtropis. Buku. Direktorat Jenderal Rehabilitasi Lahan dan Perhutanan Sosial Departemen Kehutanan. Jakarta. 530 p.

Sundari, D. dan M. W. Winarno. 2010. Efek laksatif jus daun asam jawa (Tamarindus indica Linn.) pada tikus putih yang diinduksi dengan gambir. Artikel. 20(3):100--103.

Sutopo, L. 2002. Teknologi Benih. Buku. Raja Grafindo Persada. Jakarta. 237 p.

Winarni, T. B. 2009. Pengaruh perlakuan pendahuluan dan berat benih terhadap perkecambahan benih kayu afrika (Maesopsis eminii Engl.). Skripsi. Institut Pertanian Bogor. Bogor. 76 p.

Wanafiah, K. 2001. Inhibitor benih. Scribd. Diakses 10 Juni 2014. http://www.scribd.com/ doc/102314924/Inhibitor-Benih. 
Vol. 3 No. I, Januari 2015 (1-8)

Halaman ini sengaja dikosongkan 